\title{
Pengelolaan Timbulan Sampah Untuk Menjaga Citra Industri Pariwisata Pada Daya Tarik Wisata di Bali
}

\author{
Ni Made Rai Kristina ${ }^{1 *}$, I Gusti Ketut Indra Pranata Darma ${ }^{2}$, Heny Ratnaningtyas ${ }^{3}$ \\ ${ }^{1,2}$ Fakultas Dharma Duta, Institut Hindu Dharma Negeri Denpasar \\ ${ }^{3}$ Sekolah Tinggi Pariwisata Trisakti \\ *indra163@yahoo.co.id
}

\begin{abstract}
This research aims to community movements both spontaneously and in an organized manner, such as the Trash Hero Indonesia community and other community activities that care about the high waste generation. In addition to the Trash Hero community, indepth interviews were conducted with the Waste Bank and tourist attraction in knowing the management of waste generation. It is hoped that alternative activities will be obtained to help reduce the generation of plastic waste that supports the implementation of Bali Governor Regulation number 97 of 2018. Activities from the community are expected to be able to maintain and provide a positive legacy for future generations. The purpose of this research is to find movements made by the community to help reduce the generation of plastic waste on the island of Bali. The results of this study are expected to increase public awareness of waste management both organic and non organic.
\end{abstract}

Keywords: Waste; Plastic; Tourism Image

\begin{abstract}
ABSTRAK
Penelitian ini bertujuan untuk menggali gerakan masyarakat baik secara spontan maupun terorganisir seperti pada komunitas Trash Hero Indonesia maupun kegiatan masyarakat lain yang peduli pada tingginya timbulan sampah. Selain komunitas Trash Hero, dilakukan wawancara secara mendalam ke Bank Sampah dan daya tarik wisata dalam mengetahui pengelolaan timbulan sampah. Diharapkan didapatkan kegiatan alternatif dalam membantu mengurangi timbulan sampah plastik yang mendukung dari penerapan Peraturan Gubernur Bali Nomor 97 tahun 2018. Kegiatan dari komunitas diharapkan dapat menjaga serta memberikan peninggalan positif bagi generasi mendatang. Tujuan dari penelitian ini untuk mendapatkan gerakan-gerakan yang dilakukan masyarakat dalam membantu mengurangi timbulan sampah plastik di Pulau Bali. Hasil pada penelitian ini diharapkan dapat meningkatkan kepedulian masyarakat terhadap pengelolaan sampah baik organik dan non organik.
\end{abstract}

Kata Kunci: Sampah; Plastik; Citra Pariwisata 


\section{PENDAHULUAN}

Pergerakan Industri pariwisata Bali yang bergerak pesat merupakan sebuah peluang yang sangat menjanjikan bagi masyarakat sekitar terutama masyarakat di Gianyar. Pariwisata merupakan sebuah kegiatan yang bertujuan menyelenggarakan jasa pariwisata, menyediakan atau mengusahakan objek dan daya tarik wisata, usaha sarana pariwisata dan usaha lain yang terkait di bidang tersebut (Utama, 2017). Pariwisata ini merupakan syarat suatu perjalanan disebut sebagai perjalanan pariwisata apabila perjalanan dilakukan dari suatu tempat ke tempat yang lain, di luar tempat kediaman orang tersebut biasa tinggal (Yoeti, 2003).

Pada tahun 2015, diperkenalkan sebuah era baru dalam dunia pariwisata yang disebut dengan Tourism 4.0 (Pariwisata 4.0). Menurut Kementerian Pariwisata (2019) Pariwisata 4.0 ini adalah suatu tren wisata yang menggunakan pemrosesan data secara besar-besaran (big data) yang dikumpulkan dari sejumlah besar wisatawan dalam mencapai pengalaman perjalanan yang dipersonalisasi menggunakan teknologi modern dan tinggi. Tujuan dalam pariwisata 4.0 ini adalah mengembangkan pariwisata secara cepat dengan pertumbuhan yang berlipat. Jenis wisatawan yang dituju merupakan wisatawan dengan perilaku cenderung mandiri dan individu, dalam arti mampu melakukan kegiatan wisata mandiri tanpa bergantung dengan jasa agen atau biro travel.

Perkembangan Pariwisata 4.0 ini mulai terlihat dari mulai mandirinya para wisatawan dalam mencari informasi mengenai daya tarik wisata yang diinginkan, reservasi tiket penerbangan maupun paket wisata yang mulai mandiri dan berubah dengan media digital. Berkembangnya teknologi yang pesat memiliki banyak manfaat bagi dunia Pariwisata saat ini. Jika mampu mengelola industri Pariwisata dengan baik, maka wisatawan akan dengan mudah melakukan kunjungan serta semakin tertarik dengan industri Pariwisata tersebut. Terlebih industri Pariwisata merupakan salah satu industri yang cukup rentan terhadap suatu isu tertentu, sehingga perlu dijaga dari berbagai macam isu global yang berkembang di masyarakat.

Terdapat ada beberapa hal yang perlu menjadi perhatian khusus dalam perkembangan teknologi yang modern pada industri pariwisata (Utama, 2017):

1. Pergeseran pemanfaatan tiket fisik ke tiket elektronik.

2. Kemudahan bagi setiap individu dalam melakukan reservasi.

3. Pemanfaatan seluas-luasnya bagi setiap individu dalam mengoptimalkan teknologi informasi.

Dari 3 (tiga) hal tersebut, terlihat bagaimana signifikannya peranan kemajuan teknologi saat ini. Saat ini wisatawan bisa bergerak jauh lebih bebas dalam menentukan keinginannya dalam berwisata tanpa dibatasi oleh travel agent dan penuh dengan keterbukaan informasi. Pariwisata biasanya merupakan kegiatan yang dapat langsung memberikan berdampak serta memiliki keterlibatan masyarakat disekitarnya. Pariwisata ini juga mampu menjaga hubungan antara manusia dengan manusia seperti pada penerapan Tri Hita Karana (Wiwin, 2019).

Peluang yang besar ini diimbangi dengan keindahan alam yang sudah sangat terkenal hampir diseluruh dunia. Masifnya industri pariwisata ini juga diikuti semakin meningkatnya sampah yang dihasilkan oleh industri pariwisata. Menurut lembaga Bali Partnership, jumlah sampah di Bali setiap harinya mencapai 4.28 ton yang mana sekitar $11 \%$ mengalir langsung ke laut.

Sampah merupakan sisa kegiatan sehari-hari manusia dan/atau proses alam yang padat (Undang-Undang Republik Indonesia No. 18, 2008). Pengelolaan 
sampah secara tradisional, di Bali sejak masa silam, sudah dikenal pengelolaan sampah organik secara tradisional, yaitu dengan cara menjadikan sampah sebagai makanan ternak babi dan sebagai pupuk hijau dengan menanam di sawah (Wardi, 2012). Pengelolaan sampah yang baik dapat memberikan keuntungan kepada masyarakat dalam bentuk kompos, keuntungan ekonomi dalam bentuk pendapatan desa, menampung tenaga kerja lokal dan keuntungan sosial lainnya yang tidak ternilai harganya (Rakib et al, 2013).

Banyaknya sampah plastik yang timbul baru akan dapat terurai lebih dari 400 tahun. Sampah plastik tersebut tentu menjadi masalah yang kompleks bagi Bali pada khususnya dan bumi pada umumnya. Diperlukan pemikiran dan perencanaan yang matang dalam melakukan pengelolaan sampah plastik tersebut terutamanya di industri pariwisata Bali.

Mulai dari industri pariwisata yang terkecil hingga pada objek-objek wisata yang ada di Bali diperlukan suatu tindakan yang bijaksana yang dapat menguntungkan semua pihak dengan memperhatikan lingkungan.

Penelitian ini diharapkan dapat mengetahui beberapa tindakan pengelolaan sampah baik organik maupun anorganik yang telah dilakukan di Bali.

\section{TINJAUAN PUSTAKA}

Sampah merupakan benda atau barang yang tidak digunakan lagi sehingga dibuang oleh manusia (Mulasari et al, 2016). Pengelolaan yang tepat dalam memilah sampah organik dan organik dalam membantu mengurangi banyaknya sampah menumpuk terutamanya sampah plastik pada kegiatan yang berlangsung di industri pariwisata (Suarinastuti dan Mahagangga, 2016). Pembatasan tentang timbulan sampah plastik cukup mendapat apresiasi dari Pemerintah Bali yang mengeluarkan Peraturan Gubernur Nomor 97 tahun 2018 tentang Pembatasan Timbulan Sampah Plastik yang saat ini sudah menjadi kebutuhan sehari-hari bagi masyarakat.
Sampah pada usaha pariwisata menghasilkan dari jenis organik yang dapat membusuk dan anorganik tidak dapat membusuk (Masjhoer, 2018). Proses produksi dan jasa yang diberikan kepada para wisatawan memerlukan bahan baku dan menghasilkan sampah pada akhirnya serta tidak dapat dihindari keberadaanya. Pada proses ini diperlukan sebuah kebijaksanaan dalam mengelola sampah dari setiap kegiatan. Pada industri pariwisata, kebersihan merupakan salah satu faktor yang mempengaruhi daya tarik tujuan wisata dan jika dimaksimalkan dapat menjadi sebuah sumber daya yang tidak ternilai bagi penggerak industri kreatif (Dewi, 2017).

Selain menjadi sebuah sumber daya yang tidak ternilai, sampah ini juga memiliki potensi bahaya. Sampah memiliki bahan yang berbahaya bagi kesehatan yaitu sampah B3 yang dapat meningkatkan mortalitas dan mobilitas atau menyebabkan penyakit reversible atau berpotensi irreversible atau sakit berat yang tidak dapat pulih (Artiningsih, 2008).

Dalam mengurangi sampah pada dasarnya dilakukan prinsip 3R (reduce, reuse, recycle) merupakan urutan langkah untuk mengelola sampah dengan baik. Priorotas utama adalah reduce yaitu mengurangi timbulan sampah khususnya sampah plastik dengan membawa sendiri kantung belanja, menggungakan produk yang bisa digunakan berulang kali. Reuse menggunakan kembali material yang bisa dana man untuk digunakan kembali dengan cara membuat kerajinan tangan atau proses upcycle. Recycle mendaur ulang sampah dengan meleburkan, mencacah, melelehkan atau dibentuk kembali menjadi produk baru yang umumnya mengalami penurunan kualitas. Sampah yang timbul dari industri pariwisata ini perlu menjadi perhatian serius bagi masyarakat Bali khususnya para pelaku wisata yang ada. Tingginya timbulan sampah ini jika tidak diselesaikan semaksimal mungkin di lingkup awal akan membentuk citra negatif bagi wisatawan terutama 
(Ni Made Rai Kristina, I Gusti Ketut Indra Pranata Darma dan Heny Ratnaningtyas)

wisatawan mancanegara. Citra negatif ini mulai banyak disuarakan oleh beberapa wisatawan asing yang muncul di banyak media terutama media elektronik dan media massa.

Citra daya tarik wisata menjadi sebuah media dalam mengenalkan suatu daerah wisata. Citra daya tarik merupakan keyakinan mengenai suatu tempat/destinasi hingga menimbulkan suatu perasaan tertentu bagi wisatawan dalam melakukan kegiatan wisata. (Hanif et al., 2016).

Pengembangan citra kawasan pariwisata perkotaan diperlukan pengembangan elemen pembangunan citra pariwisata dari yang paling prioritas sampai kurang prioritas (Budi, 2015). Menurut Peraturan Menteri Perdagangan No. 24/M-DAG/PER9/2011, citra bukan hanya mengenai merek sebuah produk dengan tagline tertentu . Citra ini merupakan pemberian kesan yang dibawa oleh seseorang yang datang ke suatu tempat dan ikut mempengaruhi orang lain. Citra ini akan ikut mempengaruhi ketika seseorang melakukan perjalanan.

Citra daya tarik dapat mempengaruhi keinginan wisatawan untuk berkunjung dan keinginan serta merekomendasikan daya tarik ke wisatawan lainnya. Konsep citra daya tarik dimana manajer pariwisata dan DMO merupakan salah satu faktor penting dalam pemasaran daya tarik wisata (Banyai, 2009).

Citra wisatawan saat ini akan kohesif dan ideal tentang dunia yang berniat membawa wisatawan untuk tujuan tertentu serta mengubah diri wisatawan menjadi objek tersebut. Citra daya tarik merupakan faktor yang sangat penting bagi para wisatawan untuk menentukan daya tarik mereka (Haneef, 2017). Tujuan utama dari citra daya tarik adalah mengetahui suatu kebiasaan tertentu serta membuat perencanaan yang efektif dan efisien mengenai strategi pemasaran yang efektif dalam menggaet wisatawan (Echtner dan Ritchie, 1993).

Citra daya tarik memiliki suatu dampak menjadi jembatan antara kualitas layanan dalam melakukan kunjungan, citra memperkuat hubungan layanan ketika ditambahkan dengan model tertentu.(Timur, 2018). Dalam memperbaiki citra negatif mengenai sampah ini, beberapa komunitas mulai menggiatkan pengurangan timbulan sampah terutamanya sampah plastik yang mulai meningkat. Terlebih adanya dukungan pemerintah melalui Peraturan Gubernur Nomor 97 tahun 2018 mengenai pembatasan timbulan sampah plastik sekali pakai. Salah satu komunitas yaitu Trash Hero Indonesia mulai rutin melakukan kegiatan dalam pengurangan timbulan sampah plastik tersebut.

\section{METODOLOGI PENELITIAN}

Langkah-langkah yang dipersiapkan dalam kegiatan ini antara lain adalah:

1. Memaparkan kondisi nyata dari beberapa daya tarik wisata yang banyak dikeluhkan mengenai timbulan sampah terutamanya sampah plastik.

2. Menguraikan latar belakang penelitian permasalahan di lapangan, kajian penelitian sebelumnya.

3. Pembuatan rumusan masalah yang terkait dengan latar belakang penelitian sesuai permasalahan yang terjadi.

4. Melakukan kajian literatur tentang citra pariwisata Bali

5. Merumuskan pertanyaan kepada nara sumber terkait.

6. Melaksanakan wawancara mendalam dengan informan dengan teknik pengumpulan data pertanyaan terbuka, observasi, mengumpulkan dokumentasi yang dimiliki baik dari peneliti maupun sumber ketiga terkait persoalan penelitian dan melakukan rekam suara serta merumuskan hasil wawancara.

7. Mengaitkan satu konsep dengan konsep lain.

Teknik yang dilakukan dalam memperoleh data, melalui tiga teknik utama yaitu wawancara dengan narasumber, pengamatan langsung dan studi dokumen terutamanya adalah 
penelitian terdahulu yang terkait dengan pengelolaan timbulan sampah. Teknik wawancara yang akan ditempuh akan berupa wawancara mendalam dengan nara sumber dari Komunitas Trash Hero (Pak Wayan Aksara), Pengelola Griya Luhu (Ibu Nia) dan Yayasan Tukad Bindu Denpasar (IB Ari Manik).

Observasi yang dilakukan berlokasi di Pantai Saba Gianyar sebagai daya tarik wisata pantai serta di Pura Tampaksiring Bali sebagai daya tarik wisata religi untuk mencari informasi yang sepadan antara hasil wawancara dengan hasil di lapangan mengenai timbulan sampah pada daya tarik wisata, Bank Sampah Griya Luhu Gianyar dan Yayasan Tukad Bindu Kesiman. Langkah berikutnya yang akan dilakukan berupa studi dokumen untuk mengetahui hubungan antara informasi yang didapat memiliki keterkaitan dengan teori atau mendapat jenis informasi baru yang berbeda.

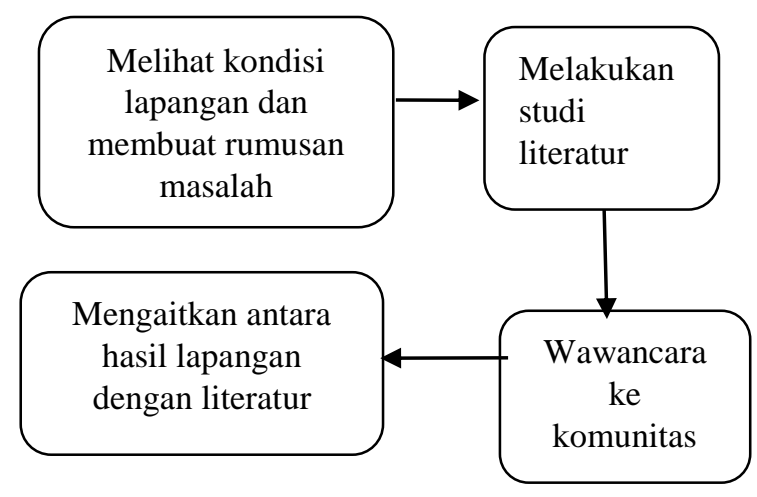

Gambar 1. Rancangan Kegiatan

Pada hasil pengumpulan data ini, dilakukan pencarian data diantaranya wawancara kepada Komunitas Trash Hero Indonesia, serta melakukan studi dokumen penelitian 10 tahun terakhir. Diperkuat juga dengan studi lapangan di beberapa titik lokasi observasi diantaranya di Pantai Saba, Kota Gianyar, Pura Tampaksiring dan beberapa tempat yang banyak menghasilkan sampah terutamanya pada Industri Pariwisata.
HASIL DAN PEMBAHASAN

Sampah dalam Industri Pariwisata

Industri Pariwisata banyak

memiliki dampak yang berkelanjutan bagi masyarakat Bali pada umumnya. Banyak jenis kegiatan yang menggantungkan hidupnya dari Industri Pariwisata ini. Beberapa Industri Pariwisata saat ini yang memberikan jasa kepada para wisatawan dan memerlukan bahan baku, hampir pasti menghasilkan sampah pada akhirnya dan tidak dapat dihindari keberadaanya (Masjhoer, 2018). Menurut pernyataan dari Bapak I Wayan Aksara selaku Ketua Komunitas Trash Hero Indonesia, Industri Pariwisata merupakan salah satu penyumbang sampah terbesar di Pulau Bali. Perlu penanganan yang spesifik untuk sampah yang ada di Bali, dengan meningkatkan penanganan sampah $10 \%$ maka akan mampu mengurangi adanya sampah yang ada di Bali.

Masih menurut Bapak Wayan Aksara, Industri pariwisata ini merupakan penyumbang sampah tertinggi di Bali selain sampah dari upakara. Contoh pada kodya Denpasar, semua jenis dicampur tanpa adanya pemilahan. Sisa-sisa sampah upakara bisa diolah menjadi kompos terlebih dahulu baru sampah residu dibawa ke TPA. 75\% sampah yang ada langsung masuk ke TPA tanpa ada pengolahan di tingkat awal seperti dalam rumah tangga, maupun di sekolah. Banyak sampah yang ada saat ini merupakan sampah organik dan sudah seharusnya diolah terlebih dahulu di tingkat awal.

Perlu tindakan nyata dalam bentuk edukasi seperti yang saat ini sudah dilakukan oleh Trash Hero Indonesia. Seperti adanya pembentukan Trash Hero Kids di luar jam sekolah dalam bentuk buku edukasi dengan melihat dan mempelajari dalam pemilahan sampah serta pemberian poin untuk kemudian dilatih pemberian hadiah. Saat ini, kegiatan nyata yang dilakukan seperti clean up di beberapa tempat sudah rutin ada hampir di seluruh Bali. Namun memang tidak hanya kegiatan seperti itu yang dirasakan perlu dilakukan. 
(Ni Made Rai Kristina, I Gusti Ketut Indra Pranata Darma dan Heny Ratnaningtyas)
Komunitas tersebut lebih
mewariskan permasalahan bagi generasi

menekankan pada edukasi kepada setiap anggota serta masyarakat dalam mengelola sampah dengan lebih bijak.

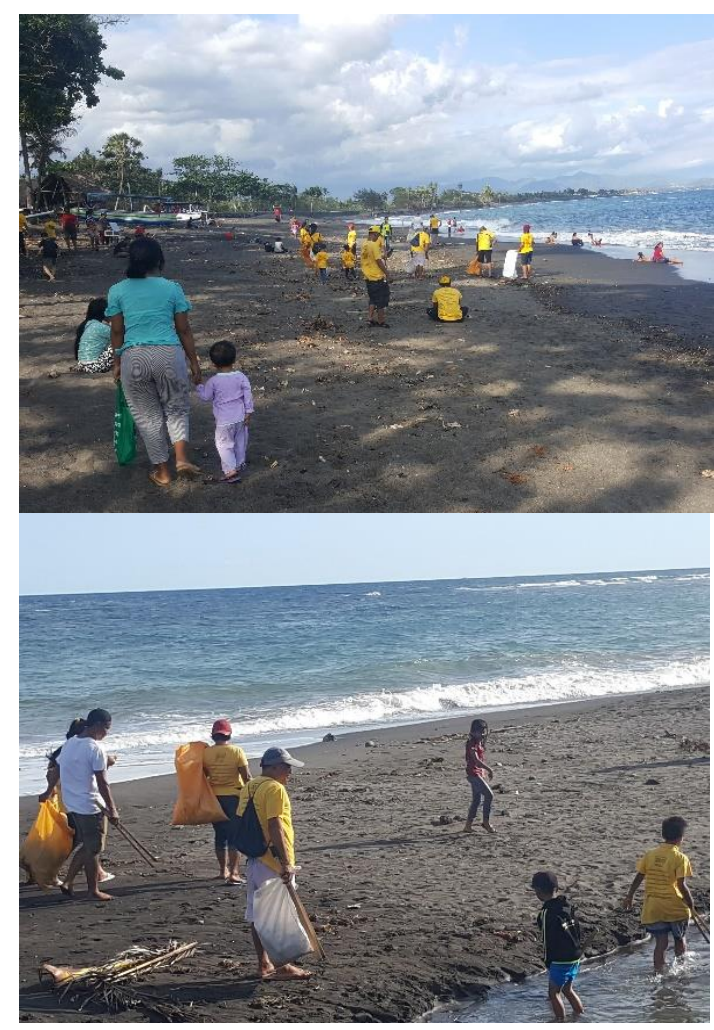

Gambar 1. Kegiatan clean up Trash Hero Indonesia (sumber: dokumentasi tim)

Lokasi-lokasi pemilihan kegiatan Trash Hero saat ini adalah tempat yang belum dikelola dengan baik oleh masyarakat maupun pemerintah. Lokasi tersebut yang dekat dengan muara-muara sampah. Seperti di barat pantai Saba pada musim penghujan. Perubahan yang saat ini dirasakan banyak perubahan perilaku pengelolaan sampah. Ini menunjukkan mulai adanya perhatian dan pola pikir bagi masyarakat.

\section{Upaya mengurangi timbulan sampah plastik}

Tingginya timbulan sampah plastik perlu menjadi perhatian khusus bukan hanya menjadi masalah pemerintah, tetapi juga bagi semua pihak. Baik industri pariwisata, desa pakraman maupun rumah tangga. Dikhawatirkan dengan tingginya sampah plastik ini akan penerus di masa yang akan datang.

Beberapa tindakan yang dapat dilakukan diantaranya:

1. Melakukan edukasi sejak dini tingkat sekolah maupun desa masalah pengelolaan sampah dalam bentuk pemilahan sampah. Selain edukasi dalam pemilahan sampah, pada komunitas Trash Hero ini juga membuat sebuah e-book yang bertujuan mengedukasi supaya anakanak mulai mengurangi benda-benda plastik. Mulai dari pengurangan tas plastik, penggunaan botol dan mengganti dengan botol refil, hingga mendaur ulang sampah.

2. Mengedukasi dalam penyelesaian sampah dalam tingkat terkecil misalkan dalam lingkup rumah tangga sebelum dibawa ke tempat pembuangan akhir (TPA). Proses edukasi dalam pemilahan sampah membutuhkan waktu yang tidak singkat.

Gerakan lain yang telah dilakukan oleh masyarakat di daerah Beng dengan mendirikan Bank Sampah Griya Luhu sejak tahun 2018. Pengumpulan sampah organik dan anorganis dengan turut serta mengedukasi anak-anak sekolah dasar telah dilakukan bekerjasama dengan lurah setempat. Pengelola Bank Sampah Griya Luhu yaitu Ibu Nia dan Ibu Dayu menyebutkan bahwa dengan menyasar anak-anak sekolah dasar diharapkan mampu menumbuhkan semangat sejak dini dalam peduli lingkungan. Bank sampah sesuai dengan namanya memiliki konsep seperti bank pada umumnya dengan model menabung saldo. Salah satu inovasi dari kegiatan ini diantaranya penggunaan aplikasi bank sampah secara digital menggantikan buku cetak sebagai bentuk meminimalisir timbulan sampah. Pengumpulan sampah-sampah anorganik yang kemudian disalurkan ke pihak ketiga menjadi pilihan Bank Sampah dalam melanjutkan proses yang ada.

Menyiapkan tempat penyimpanan seperti bank sampah dalam menampung berbagai jenis sampah seperti yang terjadi 
pada daya tarik wisata di monkey forest yang dilakukan dalam pengelolaan antara sampah organik dan non organik dalam membantu mengurangi banyaknya sampah menumpuk terutamanya sampah plastik pada kegiatan yang berlangsung (Suarinastuti dan Mahagangga, 2016). Bank sampah merupakan salah satu alternatif mengajak warga peduli sampah yang dapat dikembangkan di daerahdaerah. Bank sampah ini memiliki keunggulan dalam pemberdayaan masyarakat serta memberikan keuntungan ekonomis bagi warga.

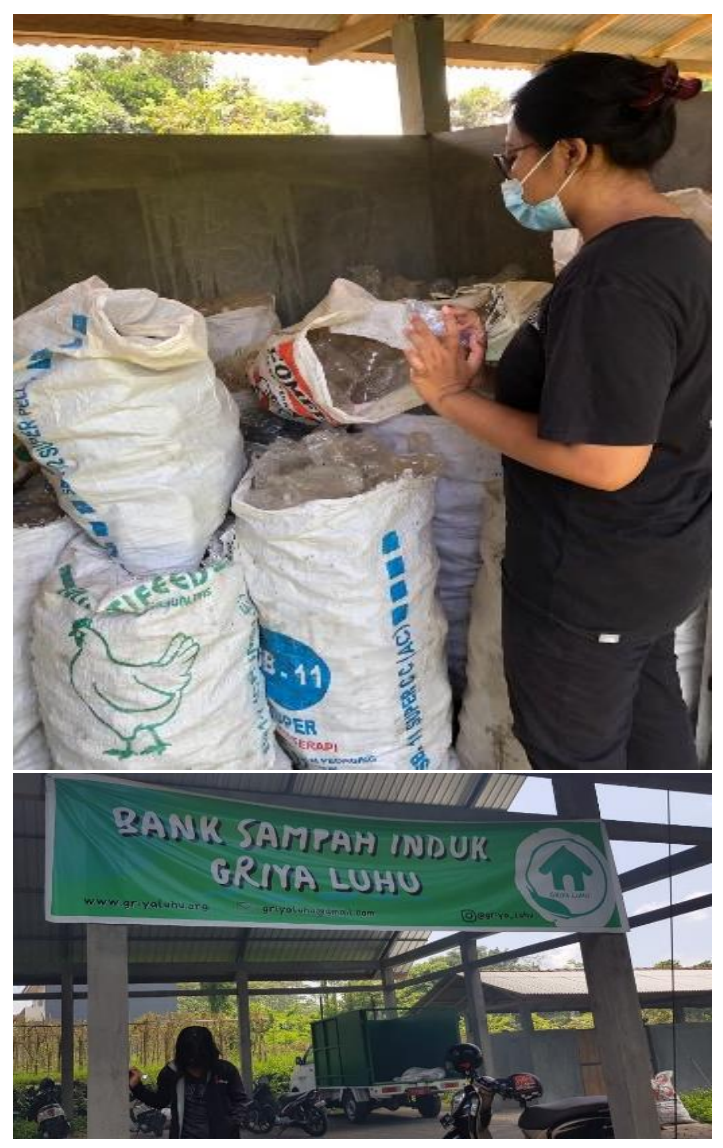

Gambar 2. Bank Sampah Griya Luhu Beng Gianyar (dokumentasi tim)

Citra daya tarik merupakan faktor yang sangat penting bagi para wisatawan memiliki tujuan utama dari citra daya tarik adalah mengetahui kebiasaan pariwisata dan merencanakan strategi pemasaran yang efektif bagi wisatawan. Optimalisasi dalam pengelolaan unit kegiatan masyarakat dalam melakukan pemilahan sampah merupakan suatu langkah efektif yang dapat dilakukan saat ini untuk menentukan daya tarik mereka (Haneef, 2017). Pemilahan yang utama saat ini dapat dimulai dalam lingkup rumah tangga yang terkecil (Masrida, 2017).

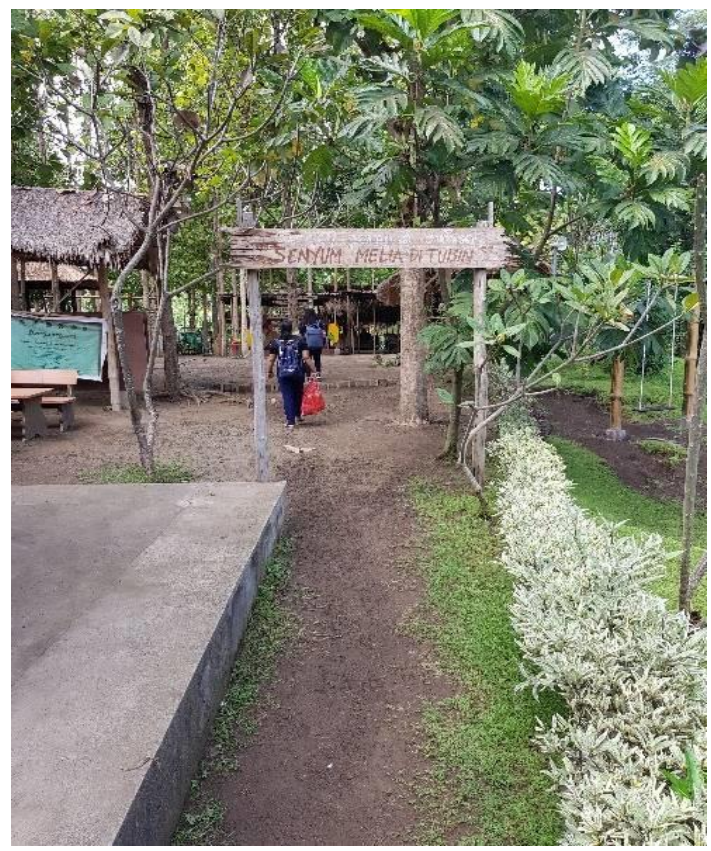

Gambar 3. Daya Tarik Wisata Tukad

Bindu Kesiman (dokumentasi tim)

Dengan pengelolaan sampah yang baik seperti pembuatan bank sampah akan membantu dalam menjaga citra pariwisata destiasi wisata seperti yang diungkapkan oleh Echtner dan Ritchie (1993), yang Ini menunjukkan bahwa citra destinasi merupakan poin penting dalam destinasi wisata manapun di Bali. Pemilahan sampah telah dilakukan oleh daya tarik wisata Tukad Bindu yang berada di kesiman Denpasar. Beberapa bentuk tanaman serta bentuk edukasi diterapkan pada daya tarik wisata Tukad Bindu. Bentuk pemilahan sampah menjadi salah satu sarana edukasi bagi masyarakat sekitar dalam pentingnya kepedulian terhadap permasalahan sampah. Pemilahan sampah menurut pengelola menjadi pembentuk citra daya tarik bagi Tukad Bindu selain aliran air sungai yang menjadi daya tarik wisata utama.

Jika ada pengelolaan sampah yang kurang baik di pulau Bali, akan menimbulkan citra yang kurang baik di mata dunia Internasional. Pandangan ini diperkuat oleh Timur (2018), dimana citra 
(Ni Made Rai Kristina, I Gusti Ketut Indra Pranata Darma dan Heny Ratnaningtyas)

destinasi memiliki efek pada kualitas layanan dan melakukan kunjungan kembali. Citra destinasi ini memperkuat hubungannya ketika ditambahkan ke model. Sehingga dapat berpengaruh terhadap pada keputusan kunjungan kembali ke suatu destinasi wisata.

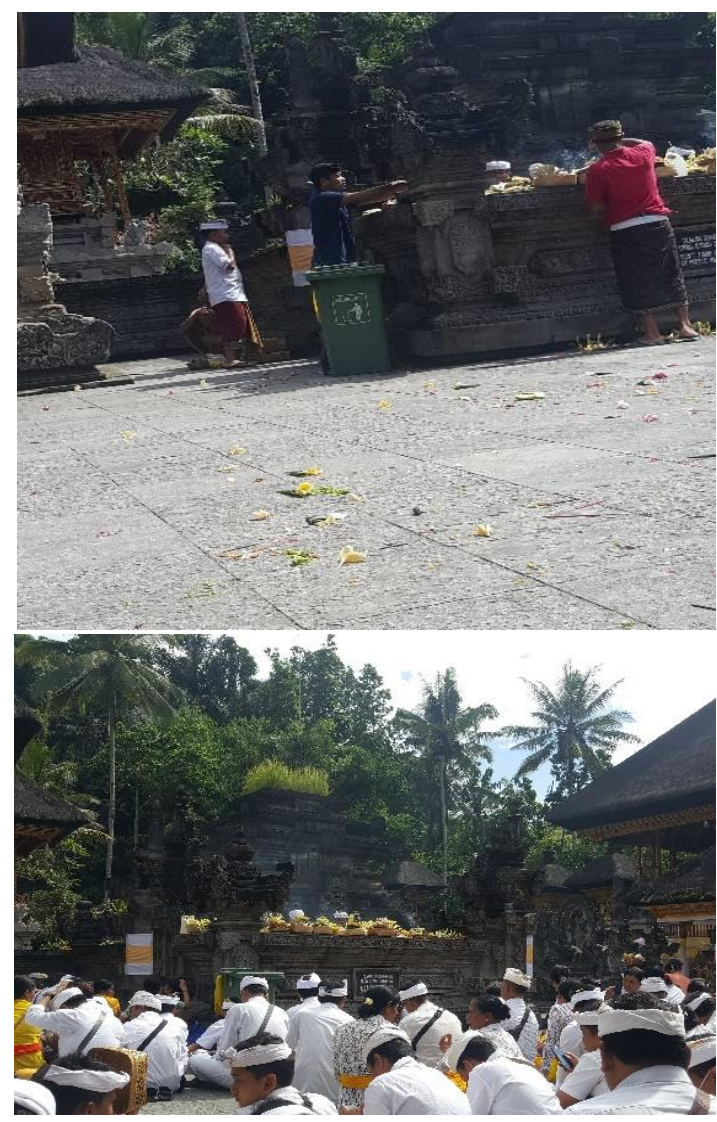

Gambar 5. Daya Tarik Wisata Pura Tirtaempul Tampaksiring (dokumentasi tim)

Pengelolaan citra destinasi yang positif membutuhkan kerjasama dari banyak pihak. Pengelolaan pariwisata berbasis masyarakat merupakan solusi dalam menjawab berbagai isu negatif tentang pengelolaan industri pariwisata saat ini (Wiwin, 2018). Isu mengenai sampah dalam industri pariwisata dapat ditangkal segera jika masyarakat lokal dilibatkan dalam pengelolaan masalah tersebut sehingga dapat menjaga citra destinasi pariwisata yang jauh dari sampah. Pengelolaan yang melibatkan masyarakat terbukti mampu meredam berbagai macam potensi gesekan antara pelaku pariwisata, pemilik daya tarik wisata serta masyarakat desa adat
(Sunarta dan Sukma, 2017). Sinergi tersebut menunjukkan pola komunikasi yang baik dalam pelibatan berbagai sektor.

Pada daya tarik wisata Pura Tampaksiring Gianyar, pengelolaan pada Pura Tirtaempul selalu melibatkan masyarakat. Salah satu bentuk nyata adalah bentuk konservasi dengan melestarikan hutan disekitar bekerjasama dengan stakeholder terkait (Sudita dan Antara, 2006). Pengelolaan daya tarik wisata dengan melibatkan masyarakat terbukti menjadi langkah yang cukup efektif sehingga berpotensi memberikan dampak pada pengelolaan sampah sisa kegiatan disekitar Pura Tiratempul.

Citra positif harus dijaga untuk tetap menarik minat wisatawan yang akan melakukan kunjungan. Dukungan pemerintah seperti adanya Peraturan Gubernur Nomor 97 tahun 2018 merupakan suatu bentuk nyata untuk mengurangi adanya timbulan sampah terutamanya sampah plastik. Sampah plastik yang ada di Indonesia berjumlah $14 \%$ dari jumlah sampah non organik belum dapat diolah (Purwaningrum, 2016). Tingginya jumlah sampah plastik tersebut cukup membahayakan dalam memberikan citra negatif bagi destinasi pariwisata.

Selain menjaga citra positif pariwisata, pengelolaan sampah yang terpadu merupakan bentuk kepedulian manusia dalam menjaga hubungan terhadap lingkungan sekitar. Terlebih lingkungan sekitar telah memberikan banyak manfaat bagi umat manusia. Bentuk kepedulian ini merupakan suatu penerapan dari Tri Hita Karana yang wajib dipertahankan untuk menjaga kelangsungan hidup manusia serta bumi supaya dapat diwariskan kepada generasi berikutnya.

Mengedukasi masyarakat tentang bahaya timbulan sampah terutama sampah plastik, tidak dapat seketika mampu mengurangi penggunaan maupun memberikan pengaruh dalam pengelolaan sampah (Fauzan et al., 1994). Penerapan teknologi dalam pengelolaan sampah 
mutlak saat ini diperlukan. Terdapat teknologi dalam mendaur ulang untuk pengolahan sampah yang saat ini masih cukup tinggi biayanya dan telah diuji pada penggunaan reaktor pirolisis 1 set merupakan salah satu yang saat ini menjadi solusi praktis dalam mengatasi timbulan sampah plastik. Pada penggunaan rektor pirolisis 1 (satu) menggunakan bahan bakar yang masih mahal dan ramah lingkungan (Jatmiko, 2017). Penggunaan teknologi ini saat ini masih dikelola untuk industri, dan perlu dikaji kembali efek samping dalam pembakaran menggunakan reaktor pirolisis ini. Bentuk lain dalam penggunaan teknologi yaitu dengan menggunakan mesin pencacah yang beberapa sudah tersebar di beberapa tempat di Bali. Mesin pencacah sampah bekerja dengan mencacah secara kecil berbagai sampah terutamanya sampah plastik. Berbagai teknologi mesin tersebut, mampu mereduksi hasil sampah secara instan meskipun masih tetap diperlukan edukasi kepada masyarakat dengan menyelesaikan tingkat timbulan sampah pada tingkat sumber baik di rumah tangga maupun di lingkungan terdekat.

\section{KESIMPULAN}

Penelitian mengenai permasalahan sampah pada citra destinasi wisata dapat diambil beberapa hal diantaranya:

1. Gerakan komunitas seperti pada Trash Hero Indonesia, bank sampah Griya Luhu dan daya tarik Wisata Tukad Bindu telah menjalankan berbagai macam bentuk edukasi kepada anakanak dan lingkungan sekitar komunitas berada. Kegiatan edukasi diperlukan dalam merubah pola pemikiran masyarakat bahwa permasalahan sampah tidak hanya menjadi tanggung jawab pemerintah tetapi menjadi perhatian bagi semua orang.

2. Penggunaan bank sampah saat ini masih menjadi alternatif solusi untuk mengurangi sampah yang dihasilkan seperti yang telah dilakukan salah satunya oleh Bank Sampah Griya Luhu, akan tetapi untuk menangani tetap diperlukan edukasi kepada masyarakat dalam pengurangan sampah seperti yang sudah dianjurkan oleh Peraturan Gubernur Bali.

3. Pengelolaan bank sampah ini harus melibatkan masyarakat lokal, karena dengan model tersebutlah akan memudahkan untuk tetap menjaga destinasi wisata dari isu-isu negatif tentang industri Pariwisata yang berkembang.

4. Beberapa teknologi yang telah ada seperti reaktor pirolisis dan mesin pencacah, mampu untuk mereduksi sampah yang tidak dapat di daur ulang. Keberadaan teknologi tersebut membutuhkan biaya yang cukup tinggi bila dibandingkan dengan potensi timbulan sampah yang ada. Maka kesadaran bagi masyarakat tentang meminimalisirkan timbulan sampah di tingkat sumber asal mutlak diperlukan bagi lingkungan terkecil pada khususnya dan lingkungan pariwisata pada umumnya.

\section{DAFTAR PUSTAKA}

Artiningsih, N. K. A. (2008). Peran Serta Masyarakat dalam Pengelolaan Sampah Rumah Tangga. Tesis. Program Magister Ilmu Lingkungan, Universitas Diponegoro.

Banyai, M. (2009). The Image of Tourism Destinations: A Case of Dracula Tourism. A Thesis. University of Waterloo Ontario Canada.

Budi, S. P. (2015). A Structural Model for The Development Competitive Tourist Destinations: a Case Study of Jakarta. Journal of Tourism, Hospitality and Sports, 3: 13-19.

Dewi, R. P. (2017). Perancangan Sistem Pengelolaan Sampah untuk Mendukung Perkembangan Industri Kreatif di Daerah Pariwisata. Prosiding Seminar Nasional Multi Disiplin Ilmu \& Papers Unisbank, 3 (Sendi_U 3): 217-221. 
(Ni Made Rai Kristina, I Gusti Ketut Indra Pranata Darma dan Heny Ratnaningtyas)

Echtner, C. M., \& Ritchie, J. R. B. (1993).

The Measurement of Destination Image: An Empirical Assessment. Journal of Travel Research, 15 (2): 3-13.

Fauzan, A., Putra, H. P., \& Yuriandala, Y. (1994). Analisis Timbulan Dan Komposisi Sampah Di Kawasan Wisata Taman Pintar Dan Sindu Kusuma Edupark D.I. Yogyakarta. Jurnal Universitas Islam Indonesia, 10 (1): 1-13.

Haneef, S. K. (2017). A Model To Explore The Impact of Tourism Infrastructure on Destination Image for Effective Tourism Marketing. Thesis. University of Salford Manchester.

Hanif, A., Kusumawati, A., \& Mawardi, M. (2016). Pengaruh Citra Destinasi Terhadap Kepuasan Wisatawan Serta Dampaknya Terhadap Loyalitas Wisatawan (Studi pada Wisatawan Nusantara yang Berkunjung ke Kota Batu). Jurnal Administrasi Bisnis S1 Universitas Brawijaya, 38 (1): 44-52.

Jatmiko, Wahyudi. (2017). Pemanfaatan Limbah Plastik Sebagai Bahan Baku Pembuatan Bahan Bakar Alternatif. Jurnal Litbang, XIV (11): 58-67.

Kementerian Pariwisata. (2019). Rencana Strategis Kementerian Pariwisata Tahun 2019-2024. Jakarta: Kementerian Pariwisata.

Peraturan Menteri Perdagangan No. 24/M-DAG/PER9/2011 tentang Ketentuan Impor dan Ekspor Hewan dan Produk Hewan.

Masjhoer, J. M. (2018). Partisipasi Pelaku Usaha Pariwisata dalam Pengelolaan Sampah di Pantai Pulang Sawal, Kabupaten Gunungkidul, Yogyakarta. Jurnal Pariwisata Terapan, 2 (2): 122-133.

Masrida, R. (2017). Kajian Timbulan Dan Komposisi Sampah Sebagai Dasar Pengelolaan Sampah Di Kampus II Universitas Bhayangkara Jakarta Raya. Journal of Env. Engineering \& Waste Management, 2(2): 69-78.

Mulasari, A., Husodo, A. H., \& Muhadjir, N. (2016), Analisis Situasi
Permasalahan

Sampah

Kota

Yogyakarta dan Kebijakan

Penanggulangannya. Jurnal

Kesehatan Masyarakat, 11 (2): 96106.

Peraturan Gubernur Bali Nomor 97 Tahun 2018. Pembatasan Penggunaan Timbulan Sampah Plastik Sekali Pakai. Denpasar: Pemerintah Daerah Bali.

Purwaningrum, P. (2016). Upaya Mengurangi Timbulan Sampah Plastik Di Lingkungan. Indonesian Journal Of Urban Environmental Technology, 8 (2): 141-147.

Rakib, M., Thaief, I., \& Sanusi, D. A. (2013). Pelatihan Kewirausahaan: Pengolahan Sampah Plastik Menjadi Produk Bernilai Jual Bagi Ibu-Ibu Rumah Tangga dan Remaja. Jurnal Dedikasi, 21 (2): 124-127.

Sunarta, N., \& Sukma, A. N. (2017). Pariwisata Berkelanjutan. Denpasar: Cakra Press.

Suarinastuti, I. A., \& Mahagangga, I. G. A. O. (2016). Pengelolaan Sampah Di Daya Tarik Wisata Wanara Wana/ Monkey Forest, Desa Padangtegal, Ubud. Jurnal Destinasi Pariwisata, 4 (2): 25-29.

Sudita, M., \& Antara, M. (2006). Nilai Sosial-Ekonomi Air di Kawasan Pura Tirta Empul Desa Manukaya, Kabupaten Gianyar, Bali: Suatu Pendekatan Ekonomi lingkungan. Soca (Jurnal Sosial Ekonomi Pertanian), 6 (2): 1-24.

Timur, B. (2018). Service Quality, Destination Image and Revisit Intention Relationships at Thermal Tourism Businesses. Journal of Gastronomy Hospitality and Travel, 1 (1): 38-48.

Undang-Undang Republik Indonesia Nomor 18 Tahun 2008 tentang Pengelolaan Sampah.

Utama, I. G. B. R. (2017). Pemasaran Pariwisata. Yogyakarta: Penerbit Andi.

Wardi, I. Nyoman. (2012). Pengelolaan Sampah Berbasis Sosial Budaya: Upaya Mengatasi Masalah 
Jurnal IImiah Pariwisata, Volume 25 No. 3 November 2020

Lingkungan Di Bali. Jurnal Bumi Lestari, 11 (1): 167-177.

Wiwin, I. W. (2018). Community Based Tourism Dalam Pengembangan Pariwisata Bali. Jurnal Pariwisata Budaya, 3 (1): 69-75.

Wiwin, I. W. (2019). Faktor Sukses Dalam Pengembangan Wisata Pedesaan. Jurnal Pariwisata Budaya 4 (2): 25-29.

Yoeti, H. O. A. (2003). Pengantar Ilmu Pariwisata. Bandung: Angkasa. 